\title{
ANALISIS STRUKTUR BALOK MENGGUNAKAN PROGRAM VISUAL BASIC
}

\author{
Ragil Jaya Kusuma ${ }^{1)}$, Arifien Nursandah ${ }^{2)}$, Dio Alif Hutama ${ }^{3)}$ \\ ${ }^{1)}$ Prodi Teknik Sipil, Fakultas Teknik, Universitas Muhammadiyah Surabaya \\ JL. Sutorejo No. 59 Surabaya, Jawa Timur, 61135 \\ E-mail: ragilkrackerr@gmail.com \\ ${ }^{2)}$ Prodi Teknik Sipil, Fakultas Teknik, Universitas Muhammadiyah Surabaya \\ JL. Sutorejo No. 59 Surabaya, Jawa Timur, 61135 \\ E-mail: arifien.nursandah@gmail.com \\ ${ }^{3)}$ Prodi Teknik Sipil, Fakultas Teknik, Universitas Muhammadiyah Surabaya \\ JL. Sutorejo No. 59 Surabaya, Jawa Timur, 61135 \\ E-mail: dioalifhutama@ft.um-surabaya.ac.id
}

\begin{abstract}
In general, the planning of a multi-story building can not be separated from the various variations of loading to obtain the appropriate dimensions of the building (safe, comfortable, and economical). Variations of loading that can be done in the form of wind, earthquake and own weight of the construction. Computer program is made to simplify and accelerate the calculation than the way cortional is by calculating the calculator manual. Here the author will explain how to make computer engineering program with vesual basic and explain the advantages of the program. Structural analysis program has a big role in construction work in the world. But the structural analysis program that has been a commercial program is generally relatively expensive. This can hinder the widespread use of the program, especially in developing countries such as Indonesia. In the current civil building planning, many programs are used to analyze structures to look for inner style values contained in the construction due to external loads, then this value is used to diminish the structure precisely and quickly. In this final project, the writer make a program for diminishing the square beam by obtaining the distance of reinforcement as well as the reinforcement dimension which is used when a certain dimension is used to withstand the force given in the construction whether the dimensions and the number of reinforcement on the beam can withstand the force given to it.
\end{abstract}

Keyword : beam, structure, visual basic

\begin{abstract}
Abstrak
Secara umum perencanaan suatu bangunan bertingkat tidak lepas dari berbagai variasi pembebanan untuk memperoleh dimensi bangunan yang sesuai (aman, nyaman, serta ekonomis). Variasi pembebanan yang dilakukan dapat berupa angin, gempa serta berat sendiri dari kontruksi tersebut. Program komputer dibuat untuk mempermudah dan mempercepat perhitungan dibandingkan cara kovesional yaitu dengan cara menghitung manual kalkulator. Disini penulis akan menjelaskan bagaimana cara membuat program komputer rekayasa dengan vesual basic dan memperjelaskan keuntungan-keuntungan dari program tersebut. Program analisa struktur mempunyai peranan besar dalam pekerjaan konstruksi di dunia. Namun program analisa struktur yang selama ini merupakan program komersil yang umumnya relative mahal. Hal ini dapat menghalangi usaha penggunaan program secara luas, terutama di negara berkembang seperti di Indonesia. Pada perencanaan bangunan sipil saat ini banyak dipakai program untuk menganalisa struktur guna mencari nilai gaya dalam yang terdapat pada konstruksi karena beban luar, kemudian nilai ini digunakan untuk mendimensi struktur tersebut secara tepat dan cepat. Dalam tugas akhir ini penulis membuat suatu program untuk mendimensi balok persegi dengan mendapatkan jarak tulangan serta dimensi tulangan yang dipakai jika dipakai dimensi tertentu untuk menahan gaya yang diberikan pada konstruksi tersebut apakah dimensi serta jumlah tulangan yang ada pada balok dapat menahan gaya yang diberikan padanya.
\end{abstract}

Kata kunci: balok, struktur, visual basic

\section{PENDAHULUAN}

Perkembangan teknologi informasi yang terjadi saat ini, baik dinegara berkembang maupun negara maju berjalan dengan pesat. Indonesia termasuk negara berkembang dan berusaha untuk mengikuti perkembangan teknologi informasi tersebut.

Perkembangan teknologi informasi termasuk di dalamnya perkembangan software (perangat lunak) sangat membantu guna memudahkan pekerjaan. Teknik sipil merupakan salah satu bidang ilmu yang menuntut pekerjaan yang cepat, tepat dalam perhitungan serta efisien dibidang waktu.

Secara umum perencanaan suatu bangunan bertingkat tidak lepas dari berbagai variasi pembebanan untuk memperoleh dimensi bangunan yang sesuai (aman, nyaman, serta ekonomis). Variasi pembebanan yang dilakukan dapat berupa angin, gempa serta berat sendiri dari kontruksi tersebut.

Program komputer dibuat untuk mempermudah dan mempercepat perhitungan dibandingkan cara kovesional yaitu dengan cara menghitung manual kalkulator. Disini penulis akan 
menjelaskan bagaimana cara membuat program komputer rekayasa dengan program visual basic dan memperjelaskan keuntungan-keuntungan dari program tersebut.

Dengan menggunakan program yang dibuat visual basic lebih unggul dalam desain grafis dan dengan tampilan yang lebih sempurna di bandingkan dengan program yang lain, kecepatan akses data yang benar jauh lebih cepat dan menggunakan bahasa yang sederhana yang mudah dipahami. Dan menggunakan peraturan SNI 2847-2013 dapat menghasilkan hitungan yang lebih tepat dan sempurna dari pada menggunakan peraturan SNI sebelumnya.

Berdasarkan uraian latar belakang diatas, maka rumusan masalah adalah sebagai berikut:Bagaimana perbandingan perhitungan dari program dan manual untuk balok tunggal dan rangkap?

Tujuan dari penelitian ini yakni untuk memperoleh perhitungan struktur beton yang lebih cepat dan tepat.

\section{TINJAUAN PUSTAKA}

Dari berbagai tipe material konstruksi, beton menjadi bagian terpenting untuk proyekproyek di Indonesia, khususnya bangunan gedung, jembatan dan jalan. Industri dalam negeri telah sepenuhnya mendukung ketersediaan material utama beton, yaitu semen dan besi beton. Maka para profesional di Industri konstruksi harus menguasai seluk beluk perencanaan dan pelaksanaan konstruksi beton. Para insinyur perencana harus mampu mendesain struktur beton yang kuat, kaku, dan ekonomis untuk berbagai tipe dan keperluan konstruksi. Struktur beton berbeda dengan struktur baja. Elemen-elemen struktur baja umumnya terdiri atas profil baja yang ada di pasaran dan ukurannnya tertentu sehingga desain lebih difokuskan pada evaluasi profil tersebut serta system sambungan yang dipilih. Sedangkan struktur beton bertulang mempunyai variasi bentuk dan ukuran yang lebih bebas sehingga perencanaan lebih menekankan pemilihan dimensi tulangan dan jaraknya (Wiryanto Dewobroto, 2005).

Penampang beton bertulang sangat bervariasi, parameternya adalah bentuk (persegi, bulat, solid, atau berongga), dimensi (ukuran), mutu beton, mutu baja tulangan dan konfigurasi pemasangan tulangan bajanya. Dari variasi parameter yang dipilih akan dihasilkan berbagai variasi kekuatan, kekakuan, daktilitas, jarak, maupun ekonomis tidaknya struktur beton yang akan dibangun (Wiryanto Dewobroto, 2005).

Dalam perencanaan struktur beton bertulang maka setiap penampang pada struktur tersebut harus direncanakan kuat terhadap setiap gaya internal yang terjadi, baik itu momen lentur, gaya aksial, gaya geser maupun torsi yang timbul sebagai respon struktur tersebut terhadap pengaruh luar.

Suatu perencanaan penampang yang optimum umumnya memerlukan proses trial- error. Dimensi penampang pada tahap awal ditetapkan terlebih dahulu, bersama- sama konfigurasi beban selanjutnya dilakukan analisis struktur untuk mencari gaya-gaya internal batang. Kemudian penampang beton dievaluasi terhadap gaya-gaya internal yang terjadi (Wiryanto Dewobroto, 2005).

Ada berbagai metode dan cara yang dapat digunakan untuk mengevaluasi perhitungan struktur, mulai dari cara yang sederhana yang dapat dikerjakan dengan manual maupun cara-cara lain yang lebih teliti tetapi lebih rumit dan memerlukan komputer. Di dalam skripsi ini akan dibahas secara detail analisis perhitungan beton bertulang dengan metode kuat batas memakai cara yang lebih teliti yaitu menggunakan pemrograman. Komputer saat ini telah menjadi suatu yang rutin dalam kehidupan sehari-hari. Sudah banyak anggota masyarakat yang memanfaatkannya karena harga yang semakin terjangkau dan kemampuannya semakin canggih, serta multi fungsi sehingga berbagai kalangan mendapat manfaatnya. Demikian juga dengan aplikasi komputer di bidang teknik sipil, sudah sangat banyak permasalahan-permasalahan rutin pekerjaan insinyur yang telah dibuatkan program komputernya. Jadi hanya masalah-masalah khusus saja yang memerlukan peng-kode-an tersendiri dengan bahasa pemrograman komputer, itu pun hanya biasa dijumpai pada komunitas peneliti/mahasiswa (Wiryanto Dewobroto, 2005).

\section{METODE PENELITIAN}

Langkah-langkah pengerjaan tugas akhir ini digambarkan dalam sebuah flowchart seperti di bawah ini

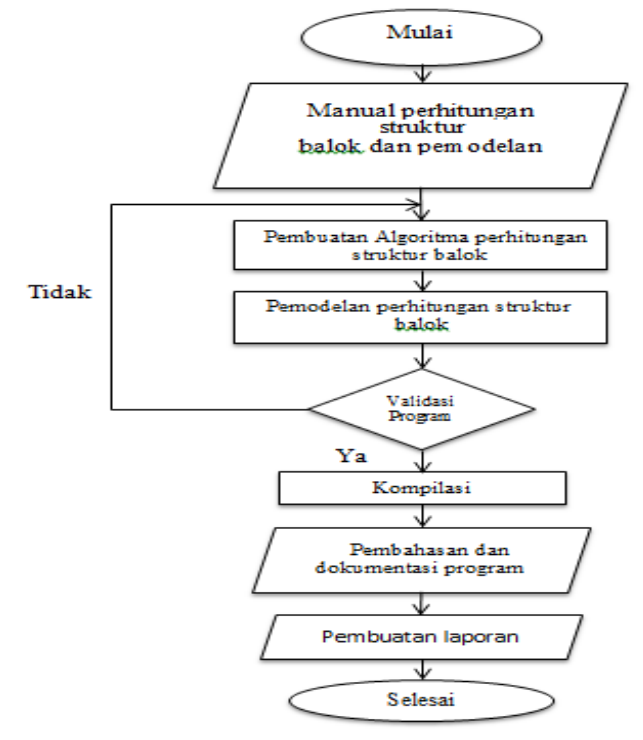




\section{Memulai Pemodelan}

Pemodelan dimulai dengan mengumpulkan berbagai landasan teori, metode yang akan digunakan, bahasa computer yang digunakan, serta berbagai hal yang menunjang pemodelan.

\section{Manual Perhitungan Struktur Beton Bertulang}

Pada tahap kedua setelah melakukan pengumpulan dasar teori dan metode yang akan digunakan maka tahap selanjutnya adalah melakukan perhitungan struktur beton bertulang secara manual, yaitu dengan melakukan perhitungan struktur beton bertulang sesuai dengan metode yang telah ditentukan secara manual. Setelah melakukan perhitungan secara manual maka tahap selanjutnya adalah melakukan studi pemodelan guna mengetahui dan memahami alur perhitungan dari metode yang digunakan.

\section{Pembuatan Algoritma}

Algoritma program dibuat berdasarkan alur langkah demi langkah dari perhitungan manual perhitungan struktur beton bertulang sesuai dengan metode yang sudah ditentukan. Algoritma disusun secara bertahap dengan memperhatikan alur dari manual perhitungan struktur beton bertulang dan kemungkinankemungkinan yang terjadi pada hasil program yang akan dihasilkan.

\section{Pemodelan Perhitungan Struktur Beton Bertulang}

Pembuatan program (pemodelan) dilakukan berdasarkan algoritma yang sudah dibuat dengan bahasa program. Program dibuat dengan pertimbangan kemudahan dalam penggunaannya, sehingga sebisa mungkin mudah untuk digunakan.

\section{Validitas Program}

Setelah software tersusun dengan baik, dilakukan validasi dengan perhitungan struktur beton bertulang tahan gempa secara manual (yang dianggap valid dan $100 \%$ benar) untuk melihat perbedaan hasil dari kedua proses tersebut baik menggunakan software maupun manual. Jika terjadi kesalahan hasil akhir, kemungkinan terjadi kesalahan pada software, sehingga dilakukan proses debugging (pencarian kesalahan pada logika program) untuk mencari kesalahan yang ada.

\section{Pembahasan dan Dokumentasi Program}

Program yang telah dikompilasi perlu untuk dibahas guna untuk merunut kekurangankekurangan yang ada pada program tersebut sehingga tidak menutup kemungkinan untuk melakukan pengembangan dan penyempurnaan program di waktu mendatang. Dokumentasi program sangat dibutuhkan guna memudahkan pengembang program dalam proses menyempurnakan dan merubah tampilan interface program.

\section{Pembuatan Laporan}

Pembuatan laporan dibuat guna mensosialisasikan program kepada para pengguna dibidang teknik sipil maupun masayrakat umum.

\section{HASIL DAN PEMBAHASAN}

Aplikasi penggunaan program ini dibuat dalam contoh hasil output yang ada kemudian dibandingkan dengan hasil output hasil perhitungan manual. Berdasarkan peraturan yang berlaku di Indonesia.

\section{Tampilan Dan Fitur Program}

\section{Cara Menggunakan Program}

Pada layar utama kita bisa memilih Balok Persegi Panjang

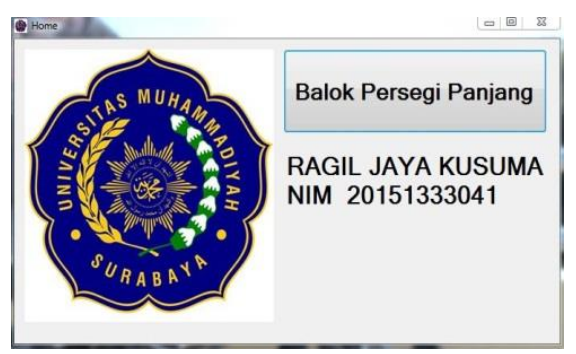

Setelah memilih Balok Persegi Panjang kita memilih apa yang kita mau hitung antara Balok Persegi Tunggal atau Balok Persegi Rankap

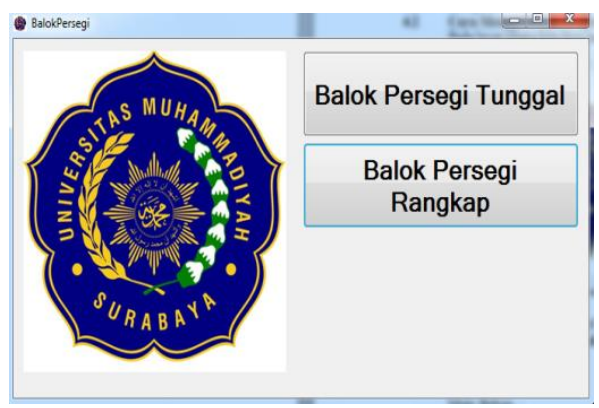

Jika kita memilih menghitung Balok Persegi Tunggal kita harus memasukkan nilai FY, FC', B, H, MU, selimut beton, tulangan utama, diameter sengkang, $\phi$, VU, dan jumlah sengkang. Stelah itu klik cari, hasil jumlah besi yang dipakai dan jarak sengkang otopatis akan keluar. Jika diameter tulangan tidak ada pada hitungan tulangan kita bisa mengisi di kolom yang kosong lalu klik cari. 


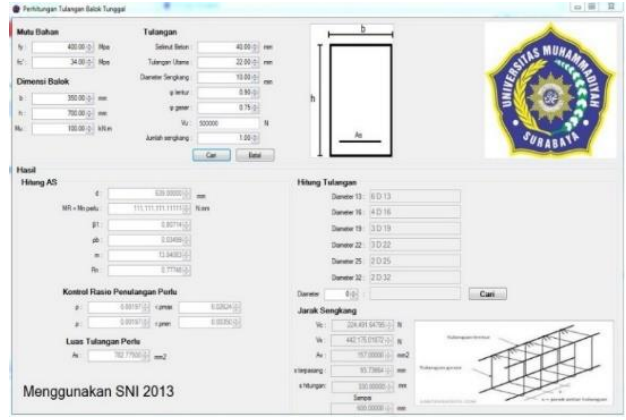

Jika kita memilih menghitung Balok Persegi Rangkap langkah-langkah pada perhitungan ini sama seperti langkahlangkah menghitung Balok Persegi Tunggal. Kita harus memasukkan nilai FY, FC', B, H, MU, selimut beton, tulangan utama, diameter sengkang, $\phi$, VU, dan jumlah sengkang. Stelah itu klik cari, hasil jumlah besi yang dipakai dan jarak sengkang otopatis akan keluar. Jika diameter tulangan tidak ada pada hitungan tulangan kita bisa mengisi di kolom yang kosong lalu klik cari.

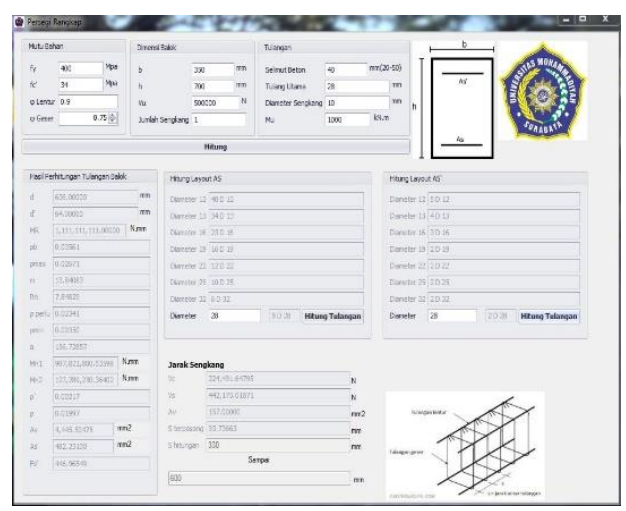

\section{Variabel Kerja}

Table 4.1 Daftar Variabel Kerja pada form Persegi Tunggal

\begin{tabular}{|l|l|l|}
\hline No & Nama variabel & Tipe Data \\
\hline 1 & D & Decimal \\
\hline 2 & {$[$ AS $]$} & Decimal \\
\hline 3 & TempMU & Decimal \\
\hline 4 & MR & Decimal \\
\hline 5 & PB & Decimal \\
\hline 6 & P1 & Decimal \\
\hline 7 & PMAX & Decimal \\
\hline 8 & PMIN & Decimal \\
\hline 9 & M & Decimal \\
\hline 10 & RN & Decimal \\
\hline 11 & PPERLU & Decimal \\
\hline 12 & MN & Decimal \\
\hline 13 & TEMPPPERLU & Decimal \\
\hline
\end{tabular}

\begin{tabular}{|l|l|l|}
\hline 14 & ASAKIR & Decimal \\
\hline 15 & TempVC & Decimal \\
\hline 16 & tempFC & Decimal \\
\hline 17 & tempB & Decimal \\
\hline 18 & TempD & Decimal \\
\hline 19 & TempH & Decimal \\
\hline 20 & tempO & Decimal \\
\hline 21 & TempVU & Decimal \\
\hline 22 & tempVS & Decimal \\
\hline 23 & TempAV & Decimal \\
\hline 24 & tempAS & Decimal \\
\hline 25 & TempS & Decimal \\
\hline 26 & tempFY & Decimal \\
\hline 27 & tempselimutbeton & Decimal \\
\hline 28 & tempDS & Decimal \\
\hline 29 & TEMP13 & Integer \\
\hline 30 & TEMP16 & Integer \\
\hline 31 & TEMP19 & Integer \\
\hline 32 & TEMP22 & Integer \\
\hline 33 & TEMP25 & Integer \\
\hline 34 & TEMP32 & Integer \\
\hline 35 & TEMTANYA & Integer \\
\hline
\end{tabular}

Table 4.2 Daftar Variabel Kerja pada form Persegi Rangkap

\begin{tabular}{|l|l|l|}
\hline No & $\begin{array}{l}\text { Nama } \\
\text { variabel }\end{array}$ & $\begin{array}{l}\text { Tipe } \\
\text { Data }\end{array}$ \\
\hline 1 & varAs & Double \\
\hline 2 & varAsAksen & Double \\
\hline 3 & as1 & Double \\
\hline 4 & Selbeton & Double \\
\hline 5 & Tulutama & Double \\
\hline 6 & Mu & Double \\
\hline 7 & diasengkang & Double \\
\hline 8 & B & Double \\
\hline 9 & H & Double \\
\hline 10 & Fy & Double \\
\hline 11 & Bawang & Double \\
\hline 12 & Fc & Double \\
\hline 13 & D & Double \\
\hline 14 & dAksen & Double \\
\hline 15 & Mr & Double \\
\hline 16 & Rho & Double \\
\hline 17 & rhoB & Double \\
\hline 18 & rhoMax & Double \\
\hline 19 & Rhomin & Double \\
\hline 20 & M & Double \\
\hline 21 & Rn & Double \\
\hline 22 & rhoPerlu & Double \\
\hline 23 & sy1 & Double \\
\hline 24 & sy2 \\
\hline & & \\
\hline 19 & & \\
\hline & & \\
\hline
\end{tabular}




\begin{tabular}{|l|l|l|}
\hline 25 & fsAksen & Double \\
\hline 26 & a & Double \\
\hline 27 & Mn1 & Double \\
\hline 28 & Mn2 & Double \\
\hline 29 & rhoAksen & Double \\
\hline 30 & bheta1 & Double \\
\hline 31 & TempVC & Decimal \\
\hline 32 & tempFC & Decimal \\
\hline 33 & tempB & Decimal \\
\hline 34 & TempD & Decimal \\
\hline 35 & TempH & Decimal \\
\hline 36 & tempO & Decimal \\
\hline 37 & TempVU & Decimal \\
\hline 38 & tempVS & Decimal \\
\hline 39 & TempAV & Decimal \\
\hline 40 & tempAS & Decimal \\
\hline 41 & TempS & Decimal \\
\hline 42 & tempFY & Decimal \\
\hline 43 & tempHasilJarak & Double \\
\hline 44 & tempDS & Decimal \\
\hline 45 & result & Decimal \\
\hline 46 & TEMP13 & Decimal \\
\hline 47 & TEMP16 & Decimal \\
\hline 48 & TEMP19 & Decimal \\
\hline 49 & TEMP22 & Decimal \\
\hline 50 & TEMP25 & Decimal \\
\hline 51 & TEMP32 & Decimal \\
\hline 52 & Tempx & Decimal \\
\hline & & \\
\hline
\end{tabular}

\section{Perhitungan Balok Secara Manual}

\section{Perhitungan Tulangan Balok Tunggal Secara} Manual

DATA PERENCANAAN :

Mutu Bahan :

$$
\begin{array}{ll}
\text { fy } & =400 \mathrm{Mpa} \\
\mathrm{fc}^{\prime} & =34 \mathrm{Mpa}
\end{array}
$$

Dimensi Balok :

$$
\begin{array}{ll}
\mathrm{b} & =350 \mathrm{~mm} \\
\mathrm{~h} & =700 \mathrm{~mm} \\
\mathrm{Vu} & =500 \mathrm{KN}
\end{array}
$$

Tulangan :

selimut beton $=40 \mathrm{~mm}$

Tul. Utama $=22 \mathrm{~mm}$

Diameter Sengkang $=10$

Jumlah sengkang $=1$

$\mathrm{Mu}=100 \quad \mathrm{kN} . \mathrm{m}=100 \times 10^{6}$ N.mm

Perhitungan Tulangan Balok :

$\mathrm{d}=h-$ selimut beton - sengkang tul.utama

$$
\begin{aligned}
& =700-40-10-\frac{22}{2} \\
& =639 \mathrm{~mm} \\
\mathrm{M}_{\mathrm{R}} & =\mathrm{Mn}_{\text {perlu }}=\frac{M u}{\varphi}
\end{aligned}
$$

$$
\begin{aligned}
& =\frac{100 \times 10^{6}}{0,9} \\
& =111111111 \text { N.mm }
\end{aligned}
$$

Karena $\mathrm{fc}^{\prime}=34 \mathrm{Mpa}>28 \mathrm{Mpa}$, maka:

$$
\begin{aligned}
\beta_{1} & =0,85-0,05 \times\left(\frac{\mathrm{fc}^{\prime}-28}{7}\right) \\
& =0,807 \\
\rho_{\mathrm{b}} & =\frac{0,85 \times \mathrm{fc} \prime}{f y} \times \beta_{1} \times\left(\frac{600}{600+f y}\right) \\
& =\frac{0,85 \times 34}{400} \times 0,807 \times\left(\frac{600}{600+400}\right) \\
& =0,0349 \\
& =0,75 \times \rho_{\mathrm{b}} \\
& =0,75 \times 0,0349 \\
& =0,03499 \\
& =\frac{f y}{0,85 \times \mathrm{fc} \prime} \\
& =\frac{400}{0,85 \times 34} \\
& =13,8408 \\
& =\frac{M n}{b \times d^{2}} \\
& =\frac{111111111}{350 \times 639^{2}} \\
& =0,7774 \\
& =\frac{1}{m} \times\left(1-\sqrt{1-\left(\frac{2 \times m \times R n}{f y}\right)}\right) \\
\rho \quad= & =0,0019 \\
\frac{1}{13,8408} \times & \left(1-\sqrt{1-\left(\frac{2 \times 13,8408 \times 0,8747}{400}\right)}\right) \\
& \quad=
\end{aligned}
$$

Kontrol rasio penulangan perlu:

$\rho=0,0019<\rho_{\max }=0,0262 ;$ maka digunakan tulangan tunggal

$\rho=0,0019<\rho_{\min }=0,0035 ;$ maka diperlukan luas tulangan minimum

Luas tulangan perlu

$$
\text { As } \quad \begin{aligned}
& =\rho_{\min } \times b \times d \\
& =0,00035 \times 350 \times 639 \\
& =782,775 \mathrm{~mm}^{2}
\end{aligned}
$$

Dipasang tulangan tarik : 3D22

Mecari jarak sengkang :

$$
\begin{aligned}
& \mathrm{d}=h-\text { selimut beton } \\
&=700-40 \\
&=660 \mathrm{~mm} \\
& \mathrm{Vc} \quad\left[\frac{\sqrt{f c \prime}}{6}\right] \times b \times d \\
&=\left[\frac{\sqrt{34}}{6}\right] \times 350 \times 660 \\
&=224491,647 \mathrm{~N} \\
& \mathrm{Vs}=\frac{500000}{0,75}-V c \\
&=625000-224491,647 \\
&=442175.018 \mathrm{~N}
\end{aligned}
$$

Karena $\mathrm{Vs}>\frac{2}{3}\left[\frac{\sqrt{f c^{\prime}}}{6}\right] \times b \times d$ sehingga tidak perlu penampang diperbesar $442175.018 \mathrm{~N}>897966.59 \mathrm{~N}$

Karena $\mathrm{Vu}>\phi . \mathrm{Vc}$ harus menggunakan tulangan geser

$$
\text { 442175.018 N>179593.32 N }
$$


Av $=\quad(2 \times$ As sengkang $) \times$ jumlah sengkang

$$
\begin{aligned}
& =\left(2 \times \frac{1}{4} \times 3,14 \times 10^{2}\right) \times 1 \\
& =157 \mathrm{~mm}^{2}
\end{aligned}
$$

Shitung

$$
\begin{aligned}
& =\frac{A v \times f y \times d}{V s} \\
& =\frac{157 \times 400 \times 660}{442175.018} \\
& =93.73 \mathrm{~mm}
\end{aligned}
$$

Karena $\mathrm{Vs}_{\mathrm{s}}<\frac{1}{3}\left[\frac{\sqrt{f c^{\prime}}}{6}\right] \times b \times d$

$$
442175.018 \mathrm{~N}<448983.3 \mathrm{~N}
$$

Maka Sterpasang $=\frac{d}{2}<600 \mathrm{~mm}$

Perhitungan Tulangan Balok Tunggal Secara Aplikasi

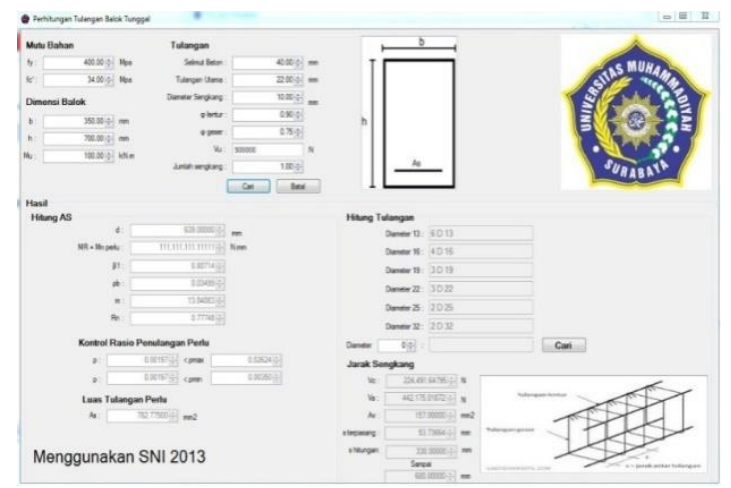

Perhitungan Tulangan Balok Rangkap Seacara Manual

\section{DATA PERENCANAAN :}

Mutu Bahan :

$\begin{array}{lll}\text { fy } & =400 & \text { Mpa } \\ \text { fc' }^{\prime}=34 & \text { Mpa }\end{array}$

Dimensi Balok :

$\mathrm{b}=350 \mathrm{~mm}$

$\mathrm{H}=700 \mathrm{~mm}$

$\mathrm{Vu}=500 \mathrm{~N}$

$\mathrm{Mu}=1000$ Perhitungan Tulangan Balok

$\mathrm{d}=h-$ selimut beton - sengkang $\frac{\text { tul.utama }}{2}$$$
=700-40-10-\frac{28}{2}=636 \mathrm{~mm}
$$$$
\text { d' } \quad=\quad \text { selimut beton } \mp \text { sengkang }+
$$
$\frac{\text { tul.utama }}{2}$
}

selimut beton $=40 \mathrm{~mm}$

Tul. Utama $=28 \mathrm{~mm}$

Diameter Sengkang $=10$

Jumlah sengkang $=1$

$$
=330 \mathrm{~mm}<600 \mathrm{~mm}
$$

$$
\begin{aligned}
& =40+10+\frac{28}{2} \\
& =64 \mathrm{~mm} \\
\mathrm{M}_{\mathrm{R}} \quad & \mathrm{Mn}_{\text {perlu }}=\frac{M u}{\varphi} \\
& =\frac{100 \times 10^{6}}{0,8} \\
& =1111111111 \text { N.mm }
\end{aligned}
$$

Karena fc' $=34 \quad$ Mpa $>28$ Mpa, maka:

$$
\begin{aligned}
\beta_{1} & =0,85-0,05 \times\left(\frac{\mathrm{fc}^{\prime}-28}{7}\right) \\
& =0,82 \\
\rho_{\mathrm{b}} \quad & \frac{0,85 \times \mathrm{fc} \prime}{f y} \times \beta_{1} \times\left(\frac{600}{600+f y}\right) \\
& =\frac{0,85 \times 34}{400} \times 0,82 \times\left(\frac{600}{600+400}\right) \\
& =0,0356 \\
& =0,75 \times \rho_{\mathrm{b}} \\
& =0,75 \times 0,0356 \\
& =0,0267 \\
& =\frac{f y}{\max 85 \times \mathrm{fc} \prime} \\
\mathrm{m} \quad & \frac{400}{0,85 \times 34} \\
& =13,8408 \\
& =\frac{M n}{b \times d^{2}} \\
& =\frac{111111111}{350 \times 636^{2}} \\
& =7,848 \\
& =\frac{1}{m} \times\left(1-\sqrt{\left.1-\left(\frac{2 \times m \times R n}{f y}\right)\right)}\right. \\
\rho \quad= & =0,0234 \\
\frac{1}{13,8408} \times & \left(1-\sqrt{1-\left(\frac{2 \times 13,8408 \times 7,702}{400}\right)}\right) \\
& =
\end{aligned}
$$

Kontrol rasio penulangan perlu:

$\rho=0,0234<\rho_{\max }=0,0267 ; \quad$ maka digunakan tulangan rangkap

$\rho=0,0234<\rho_{\min }=0,0035 ;$ memenuhi kebutuhan tulangan minimum

Tentukan tulangan meleleh:

$\left(\rho-\rho^{\prime}\right)=0,85 \times \rho \mathrm{b}$

$\left(\rho-\rho^{\prime}\right)=0,85 \times 0,03561$

$\left(\rho-\rho^{\prime}\right)=0,01842$

$\frac{1}{m} \times \beta_{1} \times \frac{d^{\prime}}{d} \times\left(\frac{600}{600-400}\right) \leq\left(\rho-\rho^{\prime}\right) \leq \rho \max$

$\frac{1}{13,8408} \times 0,82 \times \frac{64}{636} \times\left(\frac{600}{600-400}\right) \leq\left(\rho-\rho^{\prime}\right)$ $\leq 0,0267$

$0,0179 \leq 0,01842 \leq 0,0267$ 
Ditentukan

$0,0179<\left(\rho-\rho^{\prime}\right)=0,02<0,0267 \quad ; \quad$ agar tulangan tekan leleh

$$
\begin{array}{ll}
\mathrm{a} \quad & \left(\rho-\rho^{\prime}\right) \times m \times d \\
& =0,01842 \times 13,8408 \times 636 \\
& =156,728 \mathrm{~mm} \\
\mathrm{Mn}_{1} \quad & =\left(\rho-\rho^{\prime}\right) \times b \times d \times f y \times\left(d-\frac{a}{2}\right) \\
& =\quad 0,01842 \times 350 \times 636 \times 400 \times \\
\left(636-\frac{158,207}{2}\right) & =987821880 \mathrm{~N} . \mathrm{mm} \\
\mathrm{Mn}_{2} \quad & \mathrm{Mn}-\mathrm{Mn}_{1} \\
= & 1250 \times 10^{6}-987821880 \\
= & 123289230 \mathrm{~N} . \mathrm{mm} \\
\rho^{\prime} \quad & \frac{M n_{2}}{b \times d \times f y \times\left(d-d^{\prime}\right)} \\
= & \frac{123289230}{350 \times 636 \times 400 \times(636-64)} \\
= & 0,00217 \\
= & \left(\rho-\rho^{\prime}\right)+\rho \\
= & 0,01842+0,0054 \\
= & 0,01997
\end{array}
$$

Luas tulangan perlu

$$
\begin{aligned}
\text { As } & =\rho \times b \times d \\
& =0,01997 \times 350 \times 639 \\
& =4445,504 \mathrm{~mm}^{2} \\
\text { As' } \quad & \rho^{\prime} \times b \times d \\
& =0,00217 \times 350 \times 636 \\
& =482,231 \mathrm{~mm}^{2}
\end{aligned}
$$

Dipasang tulangan tarik

Tulangan Tarik $=8$ D 28

Tulangan Tekan $=2 \mathrm{D} 28$

$$
\begin{aligned}
& \text { Mecari jarak sengkang : } \\
\mathrm{d} & =h-\text { selimut beton } \\
& =700-40 \\
& =660 \mathrm{~mm} \\
\mathrm{Vc} & =\left[\frac{\sqrt{f c \prime}}{6}\right] \times b \times d \\
& =\left[\frac{\sqrt{34}}{6}\right] \times 350 \times 660 \\
& =224491,647 \mathrm{~N} \\
& =\frac{500000}{0,75}-V c \\
\mathrm{Vs} & =625000-224491,647 \\
& =442175,018 \mathrm{~N}
\end{aligned}
$$

Karena $\mathrm{Vs}_{\mathrm{s}}>\frac{2}{3}\left[\frac{\sqrt{f c^{\prime}}}{6}\right] \times b \times d$ tidak perlu penampang diperbesar

$442175,018 \mathrm{~N}>897966.59 \mathrm{~N}$
Karena $\mathrm{Vu}>\phi . \mathrm{Vc}$ harus menggunakan tulangan geser

$$
500000 \mathrm{~N}>179593.32 \mathrm{~N}
$$

Av $=$

$(2 \times$ As sengkang $) \times$ jumlah sengkang

$$
\begin{aligned}
& =\left(2 \times \frac{1}{4} \times 3,14 \times 10^{2}\right) \times 1 \\
& =157 \mathrm{~mm}^{2} \\
\text { Shitung } & =\frac{A v \times f y \times d}{V S} \\
& =\frac{157 \times 400 \times 660}{400508,352} \\
& =93,73 \mathrm{~mm}
\end{aligned}
$$

Karena $\mathrm{Vs}_{\mathrm{s}}<\frac{1}{3}\left[\frac{\sqrt{f c^{\prime}}}{6}\right] \times b \times d$

$442175,018 \mathrm{~N}<448983.3 \mathrm{~N}$

$$
\text { Maka Sterpasang } \quad \begin{aligned}
= & \frac{d}{2}<600 \mathrm{~mm} \\
& =330 \mathrm{~mm}<600 \mathrm{~mm}
\end{aligned}
$$

Perhitungan Tulangan Balok Rangkap Seacara Aplikasi

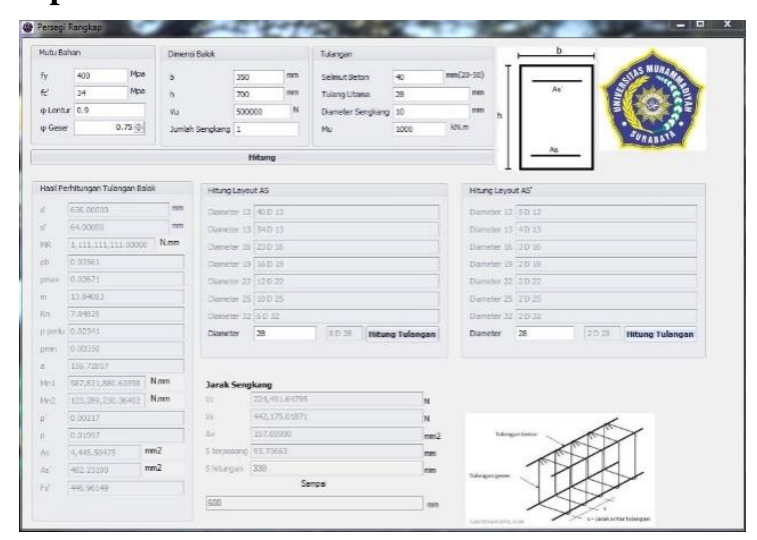

\section{SIMPULAN}

Berdasarkan hasil penelitian dapat disimpulkan sebagai berikut:

1. Program ini merupakan program yang dirancang untuk mempermudah dan mempercepat perhitungan tulangan balok dan jarak sengkang balok dengan SNI 032847-2013.

2. Hasil hitungan manual dan hasil hitungan secara program sama. Catatan: perbedanya hanya pembulatan nilai desimalnya saja.

3. Kesalahan yang dihasilkan adalah mendekati benar sehingga program ini layak untuk digunakan. 


\section{DAFTAR PUSTAKA}

Asroni, Ali. 2010. Balok dan Plat Beton Bertulang. Graha Ilmu. Yogyakarta.

Asroni, Ali. 2010. Kolom Fondasi \& Balok T Beton Bertulang. Graha Ilmu. Yogyakarta.

BSN. 2013. Persyaratan Beton Struktural Untuk Bangunan Gedung. Gd Manggala Wanabakti. Jakarta.

Chandra, Perdana. S. 2008. Kajian Program Visual Basic Untuk Perncanaaan Balok Dan Kolom. Skripsi. Universitas Sumatra Utara.

Dewobroto, Wiryanto. 2005. Aplikasi Rekayasa Konstruksi dengan

Visual Basic6.0. PT. Elex Media Komputindo. Jakarta.

Edward G, Nawi. 1998. Beton Bertulang Suatu Pendekatan Dasar. Refika Aditama, Bandung.

Harsono L, 2003. Konstruksi Beton Seri Penyelesaian. Science Cipta Series.

Istimawan, Dipohusodo. 1988. Struktur Beton Bertulang.

Imran, I., dan Hoedajanto, D. 2009. Desain dan Perhitungan Struktur Tahan Gempa (Shortcourse HAKI 2009). Himpunan Ahli Konstruksi Indonesia, Jakarta.

Martins.2013.(http://Martinsimatupang.lecture.ub.ac.id/fil es/2013/GESER/pdf, diakses 3 Januari 2018).

Nawy, E.G. 2008. Beton Bertulang Suatu Pendekatan Dasar. Refika Aditama. Bandung.

Purwono, R; Tavio; Imran, I; dan Raka, I G. P. 2007. Tata Cara Perhitungan Struktur Beton untuk Bangunan Gedung (SNI 03-2847-2002) Dilengkapi Penjelasan $(S$-2002). ITS press, Surabaya.

Yunalia.

(http://www.yunalia.staff.uii.ac.id/files/2013/06/soal2 -desain-tul-geser-yunalia.pdf, diakses 3 Januari 2018. 